\title{
Migration: An engine for social change
}

\section{The movement of people into societies that offer a better way of life is a more powerful driver of cultural evolution than conflict and conquest, say Peter J. Richerson and Robert Boyd.}

As cultural evolutionists interested in how societies change over the long term, we have thought a lot about migration, but only recently tumbled to an obvious idea: migration has a profound effect on how societies evolve culturally because it is selective. People move to societies that provide a more attractive way of life and, all other things being equal, this process spreads ideas and institutions that promote economic efficiency, social order and equality.

Culture is the set of socially acquired ideas, beliefs and values carried by a population of individuals. Various processes change the distribution of cultural variants through time. Some processes act at the individual level as people selectively learn ideas, and those ideas affect an individual's chance of teaching others or of being imitated by them, causing some cultural variants to spread and others to disappear.

$\circlearrowleft$ Theory and much empirical data indicate that individual-level processes can stabilize a vast array of beliefs and institutions.

The existence of stable differences between groups means that competition between them also affects cultural evolution. Indeed, a lot of attention has focused on what happens when militarily or economically more power-

ful societies expand at the expense of weaker ones. For example, many European ideas and institutions spread to the rest of the world as a result of colonial conquests.

Less attention has been given by cultural evolutionists to the movement of people from poorer, more chaotic or more unequal societies into richer, more orderly, more just ones - another group-level process that preoccupies much of the developed world today. People migrate to improve their lot. Although their goals and aspirations vary, most prefer wealth to poverty, safety and security to fear and danger, health to illness, and equality to inequality.

If immigrants just took advantage of the social and material benefits that their host countries provided, there would be no cultural evolution. But immigrants, and their descendants, adopt some of the ideas and institutions that make their new homes better places to live and raise families. This integration promotes the spread of ideas and institutions that encourage order, justice and economic efficiency.

We believe that immigration generates far more cultural evolution today than does conquest. Flows of migrants are often substantial. Foreign-born people, mainly from Latin America and Asia, compose about $11 \%$ of the current US population, a figure close to histori$\mathrm{cal}$ averages. The richer countries of Europe, such as Sweden, Norway and Germany, once the source of streams of immigrants to the United States and elsewhere, are now receiving people from Asia, Africa and poorer European countries such as Poland and the Balkan states.

Immigration is not a modern phenomenon. In the 1970s, anthropologist Bruce Knauft described two neighbouring village-scale societies in New Guinea, the Gebusi and the Bedamini. The Gebusi's destructive system of witchcraft trials and executions was leading
Empire. Confucian humanism, with its concern for good government, replaced the predatory and quarrelsome landed elite as the backbone of Chinese society. Hindu tolerance and productive organization of cultural diversity led to one of the world's wealthiest societies in medieval times. Medieval Islam attracted converts spanning from North Africa to southeast Asia because it supported effective statecraft, intellectual advancement and trade on a vast scale.

This way of thinking changes our view of the consequences of conflicts between societies. Focusing on military competition alone predicts that societies may be nice to insiders and rough on outsiders. Powerful societies may exploit their conquered and resist their assimilation. But taking the effects of assimilation into account suggests that conquering empires will be ephemeral unless they induce immigration and integration.

Societies that achieve more order and economic efficiency will grow even if they begin by conquest, because people are attracted to join them. Alexander the Great and Genghis Khan were successful conquerors, but they made a less durable impact on the world than, say, Mohammed, Buddha, Christ and the institution builders they inspired such as Constantine and the Umayyad caliphs. The government envisioned by Confucius, and implemented by Han Dynasty emperors centuries after his death, was the engine of assimilation for the peoples of south China. US revolutionaries and British Commonwealth reformers built societies that have proven highly attractive to incomers.

As long as they vote with their feet and hearts, immigrants are a more powerful engine for social change than armies.

Peter J. Richerson is in the Department of Environmental Science and Policy, University of California, Davis, California 95616, USA.

e-mail: pjricherson@ucdavis.edu

Robert Boyd is in the Department of Anthropology, University of California, Los Angeles, California 90095, USA. e-mail: rboyd@anthro.ucla.edu

See http://tinyurl.com/5blvmt for further reading. For more on Being Human, see www.nature.com/ nature/focus/beinghuman. mainly by voluntary conversion to eventually become the official religion in the Roman fleeing chaos on the steppe. Christianity, with
its concern for the poor and humble, grew

ideas and institutions that cause them to be richer, less violent and less exploitative than the societies that supply them. The Goths were fleeing chaos on the steppe Christianity with to their extinction. Some of the Gebusi took
advantage of friendship or marriage to join the better-functioning Bedamini. Ethnographers Likewise, the growth of ancient empires seems to have owed much to the assimilation the Mongols in China, the Mughals in India and the Goths in Rome, largely adapted to their other way around. In every case, these du -governing castes, Roman law

These examples support the idea that (c) 2008 Macmillan Publishers Limited. All rights reserved 